Penerapan Budaya Religius... Oleh: Wasito \& Moh. Turmudi

\title{
PENERAPAN BUDAYA RELIGIUS DI SD AL MAHRUSIYAH
}

\author{
Oleh: \\ Wasito \\ Moh. Turmudi \\ azzambagus8@gmail.com \\ Institut Agama Islam Tribakti (IAIT) Kediri
}

\section{Abstrak}

Penelitian ini berusaha mendiskripsikan dan memaknai penerapan budaya religius di SD al Mahrusiyah. Hal ini karena krisis moral yang melanda bangsa ini nampaknya menjadi sebuah kegelisahan bagi semua kalangan. Bagaimana tidak dari maraknya kasus korupsi yang tidak pernah surut bahkan mengalami peningkatan dari waktu ke waktu. Di sisi lain krisis ini menjadi komplek dengan berbagai peristiwa yang cukup memilukan seperti tawuran pelajar, penyalahgunaan obat terlarang, pergaulan bebas, aborsi, penganiayaan yang disertai pembunuhan. Fenomena ini sesungguhnya sangat berseberangan dengan suasana keagamaan dan kepribadian bangsa Indonesia. Jika krisis ini dibiarkan begitu saja dan berlarut-larut apalagi dianggap sesuatu yang biasa maka segala kebejatan moralitas akan menjadi budaya. Sekecil apapun krisis moralitas secara tidak langung akan dapat merapuhkan nilai-nilai kehidupan berbangsa dan bernegara.

Penelitian ini menghasilkan dua kesimpulan, yaitu; 1). Bentuk-bentuk budaya religius di SD Al Mahrusiyah meliputi belajar baca tulis al-Qur'an dan tadarrus, pemakaian busana muslim, pelaksanaan shalat jamaah di sekolah, kegiatan madin, pembiasaan senyum, sapa dan salam, berperilaku sopan santun kepada semua warga sekolah, dan doa bersama, serta peringatan hari-hari besar agama Islam. 2). Model penerapan budaya religius di SD 
Al Mahrusiyah meliputi 4 (empat) model, yaitu: pertama model struktural (melalui kebijakan dan peraturan), kedua, model formal (menanamkan commitment dan dedikasi untuk menjalankan ajaran agama), ketiga, model mekanik (membangun dan membiasakan berperilaku sopan dan santun terhadap sesame), dan keempat, model organik (melalui internalisasi dan transformasi pengetahuan tentang ajaran agama yang bersumber pada al Quran dan Hadits).

Kata Kunci : Budaya Religius, SD Al Mahrusiyah.

\section{Pendahuluan}

Krisis moral yang melanda bangsa ini nampaknya menjadi sebuah kegelisahan bagi semua kalangan. Bagaimana tidak dari maraknya kasus korupsi yang tidak pernah surut bahkan mengalami peningkatan dari waktu ke waktu. Di sisi lain krisis ini menjadi komplek dengan berbagai peristiwa yang cukup memilukan seperti tawuran pelajar, penyalahgunaan obat terlarang, pergaulan bebas, aborsi, penganiayaan yang disertai pembunuhan. Fenomena ini sesungguhnya sangat berseberangan dengan suasana keagamaan dan kepribadian bangsa Indonesia. Jika krisis ini dibiarkan begitu saja dan berlarut-larut apalagi dianggap sesuatu yang biasa maka segala kebejatan moralitas akan menjadi budaya. Sekecil apapun krisis moralitas secara tidak langung akan dapat merapuhkan nilai-nilai kehidupan berbangsa dan bernegara.

Realitas tersebut mendorong timbulnya berbagai gugatan terhadap efektifitas pendidikan agama yang selama ini dipandang oleh sebagian besar masyarakat telah gagal, sebagaimana penilaian Mochtar Buchori bahwa kegagalan pendidikan agama ini disebabkan karena praktik pendidikannya hanya memperhatikan aspek kognitif semata dari pertumbuhan nilai-nilai (agama), dan mengabaikan 
Penerapan Budaya Religius... Oleh: Wasito \& Moh. Turmudi

pembinaan aspek afektif dan konatif-volitif, yakni kemauan dan tekad untuk mengamalkan nilai-nilai ajaran agama. ${ }^{1}$

Krisis tersebut bersumber dari krisis moral, akhlak (karakter) yang secara langsung atau tidak langsung berkaitan dengan pendidikan. Krisis karakter yang dialami bangsa saat ini disebabkan oleh kerusakan individu-individu masyarakat yang terjadi secara kolektif sehingga menjadi budaya. Budaya inilah yang menginternal dalam sanubari masyarakat Indonesia dan menjadi karakter bangsa. Ironis, pendidikan yang menjadi tujuan mulia justru menghasilkan output yang tidak diharapkan. ${ }^{2}$

Pendidikan moral menjadi sangat penting bagi teguh dan kokohnya suatu bangsa. Pendidikan moral adalah suatu proses panjang dalam rangka mengantarkan manusianya untuk menjadi seorang yang memiliki kekuatan intelektual dan spiritual sehingga dapat meningkatkan kualitas hidupnya di segala aspek dan menjalani kehidupan yang bercita-cita dan bertujuan pasti. Hal ini harus menjadi agenda pokok dalam setiap proses pembangunan bangsa. ${ }^{7}$ Pendidikan moral ini bisa diaplikasikan pada penanaman nilai-nilai agama di sekolah. Untuk mewujudkan pendidikan ini maka penyelenggaraan pendidikan harus memperhatikan penanaman nilai-nilai religius dalam segala aspek aktivitas belajar.

Pendidikan pada hakekatnya merupakan upaya pewarisan nilai, yang akan menjadi penolong dan penentu umat manusia dalam menjalani kehidupan, sekaligus untuk memperbaiki nasib dan peradaban umat manusia. Tanpa pendidikan, maka diyakini bahwa manusia sekarang tidak berbeda dengan generasi manusia

${ }^{1}$ Muhaimin, Rekonstruksi Pendidikan Islam; Dari Paradigma Pengembangan, Manajemen kelembagaan, Kurikulum hingga Strategi Pembelajaran (Jakarta: Raja Grafindo Persada, 2009), h. 182.

${ }^{2}$ Agus Zaenul Fitri, Pendidikan Karakter Berbasis Nilai dan Etika di Sekolah (Yogyakarta: Ar-Ruz Media, 2012), h. 10-11. 
masa lampau, yang, telah sangat tertinggal baik kualitas kehidupan maupun proses pemberdayaannya jika dibandingkan dengan manusia sekarang. Secara ekstrim bahkan dapat dikatakan, bahwa maju mundurnya peradaban suatu masyarakat bangsa, akan sangat ditentukan oleh bagaimana pendidikan yang dijalani oleh masyarakat bangsa tersebut. Perkembangan dunia pendidikan dewasa ini begitu cepat. Sejalan dengan kemajuan teknologi dan globalisasi. Dunia pendidikan sedang diguncang oleh berbagai perubahan sesuai dengan tuntutan dan kebutuhan masyarakat, serta ditantang untuk dapat menjawab berbagai permasalahan lokal dan perubahan global yang terjadi begitu pesat. Maka dari itu, lembaga pendidikan harus mempersiapkan diri dengan meningkatkan kualitasnya.

Mutu atau kualitas saat ini menjadi satu gagasan ideal dan menjadi visi banyak orang ataupun lembaga. Karena mutu memang merupakan kualifikasi utama agar dapat survive dan tampil sebagai pemenang dalam kehidupan yang semakin kompetitif pada masyarakat yang semakin rasional. Namun demikian, untuk dapat memahami apa itu mutu ternyata ada banyak persepsi yang berbeda di masyarakat. Ketika diajukan konsep mutu, maka yang muncul kemudian adalah gambaran tentang segala hal yang "baik" dan "sempurna". Oleh karena itu, maka pasti sulit dipenuhi dan mahal. Gambaran ini sesungguhnya tidak salah, meskipun juga tidak terlalu tepat.

Namun, makna strategis mutu bagi peningkatan daya saing tersebut ternyata belum dapat diwujudkan secara maksimal dan merata dalam penyelenggaraan pendidikan di Indonesia, termasuk pada lembaga pendidikan Islam. Hal ini dapat dimengerti karena upaya perbaikan kualitas ini bukanlah hal sederhana dan dapat dilakukan secara instan. Penambahan alokasi dana belum menjamin akan dapat melahirkan lembaga pendidikan bermutu. Problem kualitas adalah problem manajemen yang cukup kompleks. Problem kualitas 
Penerapan Budaya Religius... Oleh: Wasito \& Moh. Turmudi

menyangkut filosofi dan pandangan hidup yang lebih substansial. Problem kualitas juga merupakan problem kebiasaan atau budaya yang harus ditanamkan sejak dini.

Mutu pendidikan akan tercapai, apabila didukung oleh seluruh komponen pendidikan yang terorganisir dengan baik. Beberapa komponen tersebut adalah input, proses, dan output, dan ini perlu mendapatkan dukungan sepenuhnya dari pihak yang mempunyai peran penting dalam lembaga pendidikan. Namun satu hal yang menjadi sorotan di sini adalah selama ini mutu pendidikan dinilai hanya terfokus kepada prestasi belajar, output yang diterima di perguruan tinggi unggulan, dan sebagainya. Sebaiknya hal itu ditambah dengan indikator nilainilai religius yang terinternalisasi dalam diri peserta didik. Bertolak dari hal itu, maka sangat urgen bagi lembaga pendidikan, khususnya pendidikan dasar dan menengah untuk menginternalisasikan nilai-nilai religius ke dalam diri peserta didik dengan menggunakan pembiasaan melalui budaya religius.

\section{Pembahasan}

\section{Bentuk-bentuk Budaya Religius Di SD Al Mahrusiyah Lirboyo Kediri}

Budaya religius adalah menciptakan suasana atau iklim kehidupan keagamaan. Dalam konteks sekolah berarti pelaksanaan suasana atau iklim kehidupan keagamaan yang dampaknya ialah terlaksanakannya suatu pandangan hidup yang bernafaskan atau dijiwai oleh nilai-nilai ajaran agama Islam yang biasa diwujudkan di sekolah. Budaya religius adalah sekumpulan tindakan yang diwujudkan dalam perilaku, tradisi, kebiasaan sehari-hari dan simbol-simbol yang dipraktekkan berdasarkan agama oleh kepala sekolah, guru, petugas administrasi, peserta didik dan masyarakat sekolah. Sebab itu budaya religius tidak hanya berbentuk simbolik semata sebagaimana yang tercermin di atas, tetapi dialaminya penuh 
dengan nilai-nilai. Budaya religius juga tidak hanya muncul begitu saja, tetapi melalui proses pembudayaan.

Koentjoroningrat menyatakan proses pembudayaan dilakukan melalui tiga tataran yaitu: Pertama, tataran nilai yang dianut, yakni merumuskan secara bersama nilai-nilai agama yang disepakati dan perlu laksanakan di sekolah, untuk selanjutnya dibangun komitmen dan loyalitas bersama di antara semua warga sekolah terhadap nilai-nilai yang disepakati. Kedua, tataran praktek keseharian, nilai-nilai keagamaan yang telah disepakati tersebut diwujudkan dalam bentuk sikap dan perilaku keseharian oleh semua warga sekolah. Ketiga, tataran simbol-simbol budaya, yaitu mengganti simbol-simbol budaya yang kurang sejalan dengan ajaran dan nilai-nilai agama dengan simbol budaya yang religius.

Berdasarkan temuan penelitian, wujud budaya religius di SD Al Mahrusiyah meliputi: belajar baca tulis al-Qur`an dan tadarrus, pemakaian busana muslim, pelaksanaan shalat jamaah di sekolah, belajar mentoring keislaman, pembiasaan senyum, sapa dan salam, berperilaku sopan santun kepada semua warga sekolah, doa dan istighasah bersama, serta peringatan hari-hari besar agama Islam.

a. Belajar Baca Tulis al-Qur'an, Tadarrus dan Hafalan Juz 'Amma

Baca tulis al-Quran, taddarus, dan hafalan juz 'amma (Juz ke 30 dari al Qur'an) oleh SD Al Mahrusiyah dimasukkan kedalam program ekstra kurikuler. Selain itu pembelajaran bahasa Arab tingkat juga sudah diajarkan melalui program ekstra kurikuler. Berbeda dengan sekolah dasar lainnya yang hanya memberikan materi pelajaran keagamaan hanya pada satu mata pelajaran, yaitu PAI (Pendidikan Agama Islam).

3 Koentjaraningrat, Kebudayaan, Mentalitas dan Pembangunan (Jakarta: Gramedia, 1989), h. 32. 
Penerapan Budaya Religius... Oleh: Wasito \& Moh. Turmudi

Dalam wawancara yang peneliti lakukan dengan kepala sekolah, beliau menyatakan bahwa:

Kami memasukkan pembelajaran al Quran, tadarrus dan hafalan juz 'Amma adalah karena kami ingin menciptakan suasana Islami di sekolah kami, hal ini juga karena SD Al Mahrusiyah sendiri merupakan sekolah formal yang satu atap dengan Pondok Pesantren Al Mahrusiyah Lirboyo Kediri. Dan dalam pelaksanaannya program tersebut menjadi tanggung jawab guru PAI. ${ }^{4}$

Pembelajaran al Quran, dan hafalan juz 'amma sebenarnya merupakan bagian dari materi PAI SD, namun dikarenakan jam pelajaran pada materi PAI sangat terbatas, sementara pembelajaran al Quran dan hafalan juz'amma membutuhkan waktu yang relatif lama sehingga SD Al Mahrusiyah memberikan tambahan jam dengan memasukkan program tersebut sebagai program ekstrakurikuler. Hal ini dirasakan dampaknya oleh guru PAI, sebagaimana hasil observasi yang peneliti lakukan bahwa siswa yang mengikuti kegiatan ektrakurikuler pembelajaran al Quran, taddarus dan hafalan al Quran sangat mudah memahami pelajaran PAI pada materi tajwid, membaca surat-surat pendek. Umumnya mereka telah lancar membaca al Quran surat-surat pendek, karena para siswa telah menghafalnya pada kegiatan ekstrakurikuler. ${ }^{5}$

\section{b. Pemakaian Busana Muslim}

Sampai hari ini, mayoritas ulama masih menyatakan bahwa jilbab merupakan budaya religius yang terbentuk dari nilai-nilai Islam. Di masyarakat kita sendiri, jilbab masih menjadi budaya yang terkait erat dengan unsur-unsur keislaman. Forum-forum keislaman seperti pengajian, majlis taklim, dan

\footnotetext{
${ }^{4}$ Hasil wawancara dengan kepala sekolah SD Al Mahrusiyah Lirboyo Kediri pada tanggal 25 April 2017.

5 Hasil observasi pada tanggal 25 April 2017 tentang pembelajaran PAI.
} 
acara-acara televisi di bulan Ramadhan selalu ditandai dengan pemakaian jilbab untuk kaum perempuan, meski dalam keseharian mereka belum tentu itu senantiasa mereka memakainya. Budaya religius ini juga dilestarikan di SD Al Mahrusiyah bagi siswinya. Khusus untuk siswa putra, sekolah juga mewajibkan pemakaian celana panjang, baju lengan panjang, dan memakai kopiah sebagai ciri khas budaya pesantren.. Upaya ini dilakukan untuk mendorong siswa berbusana sopan dan Islami. ${ }^{6}$

Awalnya, pakaian dirancang sebagai sarana dan cara melindungi diri dari dingin dan unsur-unsur mengganggu lainnya. Sejak bahwa pakaian periode waktu telah berkembang tidak hanya menjadi perpanjangan dari kepribadian kita, tetapi sebagai simbol status mana yang lebih baik dari individu mana mengenakan kain halus dan perhiasan daripada miskin. Hari ini, sementara pakaian yang masih digunakan sebagai simbol status, lebih mudah untuk menciptakan penampilan yang statusnya lebih tinggi dengan menggunakan pakaian yang Anda kenakan untuk menonjolkan tubuh Anda dengan cara yang mencerminkan orang-orang yang statusnya lebih tinggi.

Baju seragam memberi informasi tentang tingkat dan status orang kepada kita; banyak orang percaya bahwa pakaian dan cara berpakaian juga menunjukkan hal yang sama. Dalam beberapa penelitian, orang-orang yang menerima bantuan yang lebih besar atau permohonannya lebih mudah dikabulkan (misalnya, untuk mendatangi petisi) bila mereka berpakaian resmi atau rapih daripada bila mereka berpakaian biasa atau serampangan. Satu penelitian tentang janggut menemukan bahwa menurut wanita, pria berjanggut lebih menarik, "memiliki status lebih baik" dalam pandangan pria lainnya, dan janggutnya ini menciptakan jarak sosial yang lebih besar antara ia dengan pria lainnya yang tidak berjanggut.

\footnotetext{
${ }^{6}$ Hasil Observasi pada tanggal 25 April 2017.
} 
Penerapan Budaya Religius... Oleh: Wasito \& Moh. Turmudi

Kadang-kadang kita berpakaian agar mengesankan bagi orang lain, agar lebih menyerupai mereka, atau -bila kita mengenakan pakaian yang berlawanan dengan norma yang dianut sekelompok orang- untuk mengekspresikan penolakan kita atas nilai-nilai mereka. Untuk itu, sebagaimana yang dikatakan oleh Kepala sekolah SD Al Mahrusiyah dalam wawancara menyatakan bahwa:

"Membudayakan berbakaian secara rapi dan sesuai dengan ajaran Islam perlu ditanamkan sejak usia dini. Karena Islam mengajarkan untuk berbakain yang baik dan bersih namun tidak berlebihan. Sehingga kami, selain karena SD Al Mahrusiyah merupakan sekolah formal yang berbasis pesantren-juga membiasakannya berpakaian ala santri sejak dini.",

\section{c. Pelaksanaan Shalat Jamaah di Sekolah}

Shalat merupakan ritual wajib setiap umat Islam. Dalam Islam shalat merupakan amaliyah pertama setelah seseorang bersyahadat untuk menunjukkan keIslamannya. Sebagai rukun Islam yang kedua, shalat menjadi tolok ukur keislaman seseorang, oleh karenanya Rasulullah saw menyatakan bahwa amal seseorang yang mula -mula akan dihisab adalah shalat.

Terkait dengan hal ini, SD Al Mahrusiyah baru dapat mendorong amaliah shalat para siswanya melalui diwajibkannya shalat jamaah bersama di sekolah. Hal ini penting untuk dilakukan demi mengajarkan secara aplikatif ajaran Islam pada siswa dan guna memperkuat tali silaturrahim dan mempersatukan ikatan emosional antara kepala sekolah dengan warga sekolah, antara guru dan siswa, antara siswa dengan sesama siswa serta seluruh karyawan yang ada.

Selain shalat maktubah (shalat yang diwajibkan bagi semua umat Islam) siswa SD Al Mahrusiyah juga diwajibkan melaksanakan shalat dhuha. Bahkan jama'ah shalat dhuha

${ }^{7}$ Hasil wawancara dengan kepala sekolah SD Al Mahrusiyah Lirboyo Kediri pada tanggal 25 April 2017.

Volume 29 Nomor 1 Januari-Juni 2018 
dicantumkan dalam jadwal pelajaran sekolah, sehingga semua siswa beserta guru memiliki kewajiban untuk melaksanakan shalat dhuha berjamaah. Sebagaimana yang diutarakan oleh kepala sekolah SD Al Mahrusiyah, Muinuddin, menurutnya :

Kami memberikan waktu khusus untuk shalat dhuha berjamaan didalam jadwal mata pelajaran. Hal ini karena anak usia sekolah dasar merupakan usia emas untuk membiasakan diri melaksanakan ibadah secara disiplin. Karena kedisiplinan dalam menjalankan ibadah itu sangat penting dikemudian hari ketika mereka dewasa. Sehingga kami membiasakannya sejak usia dini. ${ }^{8}$

Dengan dibiasakannya anak usia dini untuk melaksanakan shalat dhuha, diharapkan menjadi kebiasannya pula pada kehidupannya kelak/ketika mereka dewasa. Meskipun shalat dhuha hanya merupakan shalat yang disunnahkan, tetapi hal ini penting untuk ditanamkan sejak dini, karena menurut ajaran Islam shalat dhuha merupakan shalat yang memberikan manfaat pada kelancaran rizqi seseorang.

d. Pembiasaan Senyum, Sapa dan Salam

Islam sangat menganjurkan setiap pemeluknya untuk memberikan sapaan pada orang lain dengan mengucapkan salam. Ucapan salam di samping sebagai sapaan dan doa bagi orang lain juga sebagai bentuk persaudaraan antar sesama manusia. Secara sosiologi sapaan dan salam dapat meningkatkan interaksi antar sesama, dan berdampak pada rasa penghormatan sehingga antara sesama saling dihargai dan dihormati.Pembiasan senyum, sapa dan salam merupakan ciri khas SD Al Mahrusiyah.

Budaya religius ini dilaksanakan sebagai manivestasi nilai-nilai Islam dalam pribadi muslim. Budaya religius senyum, sapa dan salam bertujuan agar warga sekolah memiliki tata

${ }^{8}$ Hasil wawancara dengan kepala sekolah SD Al Mahrusiyah Lirboyo Kediri pada tanggal 25 April 2017. 
Penerapan Budaya Religius... Oleh: Wasito \& Moh. Turmudi

krama dan rasa saling menghormati. Pembiasan senyum, sapa dan salam juga ditekankan kepada seluruh siswa-siswi baru yang dimaksudkan agar sejak dini siswa bisa mengikuti budaya religius yang sudah dilaksanakan oleh warga sekolah.

e. Program Madin

Madin adalah singkatan dari Madrasah Diniyah. SD al Mahrusiyah memasukkan materi Madin dalam jadwal pelajaran dan menjadi mata pelajaran. Namun tidak seperti mata pelajaran lain yang memiliki durasi jam yang cukup lama, madin hanya berdurasi 30 menit yaitu pukul $08.00 \mathrm{~s} / \mathrm{d} 08.30$ setelah shalat dhuha berjamaah. Materi yang diajarkan dalam madrasah diniyah tersebut adalah melatih anak untuk menulis pegon (menulis bahasa Indonesia dengan menggnakan huruf Arab). ${ }^{9}$ Hal ini untuk menunjang dan melatih kemampuan siswa dalam menulis bahasa arab dan membaca tulisan pegon yang banyak ditulis oleh kalangan pesantren.

\section{f. Doa Bersama}

Pada dasarnya do'a adalah permohonan. Do'a ini dipanjatkan untuk meminta atau memohon sesuatu yang dibutuhkan. Sedangkan, istighatsah adalah minta bantuan agar dilepaskan dari kesusahan dan kebinasaan.

Allah memerintahkan manusia agar selalu berdo'a dan merendahkan diri pada-Nya serta menjanjikan akan mengabulkan do'a dan mewujudkan apa yang diminta itu. Katakata doa banyak sekali terdapat didalam Al-Qur'an dan masingmasing mempunyai makna tertentu.

Doa itu ialah melahirkan kehinaan dan kerendahan diri serta menyata kan keinginan dan ketundukan kepada Allah. Dengan demikian, terkait dengan budaya doa di SD Al Mahrusiyah yang dilaksanakan oleh semua warga sekolah sebelum melaksanakan pembelajaran.

\footnotetext{
${ }^{9}$ Hasil Observasi Hasil pada tanggal 25 April 2017.
}

Volume 29 Nomor 1 Januari-Juni 2018 
Tidak ada yang salahnya dalam hal berdoa dan acara-acara ritual ini. Bahkan, hal semacam ini cukup bagus untuk menyeimbangkan antara berpikir dan berdzikir. Nuansa religius memang perlu ditanamkan kepada para siswa-siswi. Boleh jadi, dengan begitu, mereka bisa menjadi lebih tenang, lebih konsentrasi dan berani menghadapi proses pembelajaran, ujian dengan kesiapan mental yang penuh tawakkal.

Ada 2 hal penting yang ditanamkan kepada para siswa di SD Al Mahrusiyah, selain dari sekedar doa bersama. Pertama, manusia hanya wajib berikhtiar dan berusaha, sedangkan keputusan akhir adalah takdir Allah. Kedua, tujuan bersekolah adalah mencari ilmu yang bermanfaat bagi kehidupan dunia-akhirat, bagi masa depan yang lebih cerah, bukan hanya ketentuan lulus atau tidak lulus. Masa depan tidak hanya dipastikan dari selembar ijazah atau nominal angka-angka yang terkadang nilainilai itu tidak menggambarkan kemampuan yang sebenarnya. $^{10}$

g. Kegiatan seni dan kegiatan yang bernuansa Islami

Selain membudayakan ajaran dan nilai-nilai Islam dalam kehidupan sehari-hari, SD Al Mahrusiyah juga mengembangkan bakat dan minat santri yang bernuansa Islami melaui kegiatan seni Rebana dan kaligrafi. Hal ini selain untuk mengebangkan bakat dan minat siswa juga untuk mengenalkan seni yang bernuansa Islami.

Selain mengembangankan bakat siswa dan mengenalkan siswa pada kesenian Islam, SD al Mahrusiyah juga mengembangkan bakat penting yang menunjang penerapan budaya Islam seperti lomba da'I cilik, lomba hafalan surat-surat pendek dan lomba lainnya yang dapat menunjang pada pengembangan bakat dan minat siswa.

${ }^{10}$ Hasil wawancara dengan kepala sekolah SD Al Mahrusiyah Lirboyo Kediri pada tanggal 25 April 2017. 
Sebagaimana yang dijelaskan oleh kepala sekolah SD Al Mahrusiyah Lirboyo Kediri yang menyatakan bahwa :

"Kami juga mendorong dan mengembangkan bakat siswa melalui lomba-lomba yang diadakan pada saat kegiatan peringatan hari besar Islam seperti peringatan Maulid Nabi Muhammad SAW. Selain mengadakan lomba sendiri, kami juga mendelegasikan siswa yang memiliki bakat untuk tampil mengikuti lomba di tingkal daerah untuk menambah mental siswa saat tampil didepan orang banyak yang belum dia kenali" 11

Dalam kontek sekolah berarti pelaksanaan suasana atau iklim kehidupan keagamaan yang dampaknya ialah terlaksanakannya suatu pandangan hidup yang bernafaskan atau dijiwai oleh nilai-nilai ajaran agama Islam yang biasa diwujudkan di sekolah. Budaya religius adalah sekumpulan tindakan yang diwujudkan dalam perilaku, tradisi, kebiasaan sehari-hari dan simbol-simbol yang dipraktekkan berdasarkan agama oleh kepala sekolah, guru, petugas administrasi, peserta didik dan masyarakat sekolah. Sebab itu budaya religius tidak hanya berbentuk simbolik semata sebagaimana yang tercermin diatas, tetapi dialaminya penuh dengan nilai-nilai. Budaya religius juga tidak hanya muncul begitu saja, tetapi melalui proses pembudayaan.

Koentjoroningrat menyatakan proses pembudayaan dilakukan melalui tiga tataran yaitu: Pertama, tataran nilai yang dianut, yakni merumuskan secara bersama nilai-nilai agama yang disepakati dan perlu laksanakan di sekolah, untuk selanjutnya dibangun komitmen dan loyalitas bersama di antara semua warga sekolah terhadap nilai-nilai yang disepakati. Kedua, tataran praktek keseharian, nilai-nilai keagamaan yang telah disepakati tersebut diwujudkan dalam bentuk sikap dan perilaku keseharian oleh semua warga sekolah. Ketiga, tataran

${ }^{11}$ Hasil wawancara dengan kepala sekolah SD Al Mahrusiyah Lirboyo Kediri pada tanggal 25 April 2017.

Volume 29 Nomor 1 Januari-Juni 2018 
simbol-simbol budaya, yaitu mengganti simbol-simbol budaya yang kurang sejalan dengan ajaran dan nilai-nilai agama dengan simbol budaya yang religius.

Berdasarkan temuan penelitian, wujud budaya religius di SD Al Mahrusiyah meliputi: belajar baca tulis al-Qur'an dan tadarrus, pemakaian busana muslim, pelaksanaan shalat jamaah di sekolah, kegiatan madin, pembiasaan senyum, sapa dan salam, berperilaku sopan santun kepada semua warga sekolah, dan doa bersama, serta peringatan hari-hari besar agama Islam.

Cara berbapakain contohnya, Kadang-kadang kita berpakaian agar mengesankan bagi orang lain, agar lebih menyerupai mereka, atau -bila kita mengenakan pakaian yang berlawanan dengan norma yang dianut sekelompok orang- untuk mengekspresikan penolakan kita atas nilai-nilai mereka. Ini menunjukkan bahwa cara berpakaina merupakan ungkapan dari pengakuan dan aktualisasi kelompok social tertentu (Islam dalam hal ini).

Penelitian tentang hubungan antara pakaian dan kepribadian membuktikan bahwa bila anda amat memperhatikan cara anda berpakaian, anda cenderung mengalah dan gelisah; bila anda relatif kurang memperhatikan pakaian anda, mungkin anda seorang pribadi yang agresif dan mandiri. ${ }^{13}$ (Hasil penelitian ini berlaku untuk pria dan wanita) Melalui baju yang kita pakai, kita sering mengkomunikasikan kepatuhan atau ketidakpatuhan kita atas nilai-nilai tradisional. Pada umumnya, orang-orang akan menerima cara berpakaian yang amat tidak biasa bila pemakainya adalah orang kaya atau orang terkenal. Sebenarnya, orang-orang sering

12 Koentjaraningrat, Kebudayaan, Mentalitas dan Pembangunan (Jakarta: Gramedia, 1989), h. 32.

13 http://nuansakomunikasi.blogspot.co.id/2012/11/pakaian-danmakna-simbolik.html. 
Penerapan Budaya Religius... Oleh: Wasito \& Moh. Turmudi

\section{Model Penerapan Budaya Religius Di SD Al Mahrusiyah Lirboyo Kediri}

Secara umum, budaya dapat terbentuk secara preskriptif dan dapat juga secara terprogram sebagai learning process atau solusi terhadap suatu masalah. Yang pertama, adalah pembentukan atau pembentukan budaya religius sekolah melalui penurutan, peniruan, penganutan dan penataan suatu skenario yang berupa tradisi dan perintah dari atas atau dari luar pelaku budaya yang bersangkutan.

Untuk mengimplementasikan budaya religius di sebuah lembaga pendidikan dibutuhkan apa yang disebut dengan model. Model biasanya dianggap benar, tetapi bersifat kondisional. Oleh karena itu, model penciptaan budaya religius sangat dipengaruhi oleh situasi dan kondisi tempat model itu akan diterapkan beserta penerapan nilai-nilai yang mendasarinya. Pada dasarnya model penciptaan budaya religius sama dengan model penciptaan suasana religius. Karena budaya religius pada mulanya selalu didahului oleh suasana religius. Model penciptaan budaya religius di di SD Al Mahrusiyah berdasarkan data yang peneliti dapatkan, setidaknya dapat dipilah menjadi empat macam, antara lain. ${ }^{14}$

a. Model Struktural

Budaya religius yang ada di lembaga pendidikan biasanya bermula dari penciptaan suasana religius yang disertai penanaman nilai-nilai religius secara istiqamah. Penerapan suasana religius dapat dilakukan dengan mengadakan kegiatan keagamaan di lingkungan lembaga pendidikan. Karena apabila tidak diciptakan dan dibiasakan, maka budaya religius tidak akan terwujud.

14 Muhaimin, dkk, Paradigma Pendidikan Islam: Upaya Mengefektifkan Pendidikan Agama Islam di Sekolah (Bandung: Remaja Rosdakarya, 2008), h. 79.

Volume 29 Nomor 1 Januari-Juni 2018 
Penerapan suasana religius yang dilaksanakan oleh SD Al Mahrusiyah yang pertama memanfaatkan kekuasaan yang dimiliki oleh pimpinan SD Al Mahrusiyah, yaitu melalui penyusunan segenap peraturan dan tata-tertib bagi semua warga sekolah. Sebagaimana yang dijelaskan oleh kepala sekolah SD Al Mahrusiyah.

"Pertama-tama kami membuat peraturan yang mewajibkan semua warga sekolah untuk menjalankan budaya yang bernuansa Islami, seperti memasukkan jamaah shalat dhuha kedalam jadwal pelajaran. Karena jika sudah ada di jadwal dan tidak dilaksanakan, maka akan mendapatkan sanksi, dan dengan adanya sanksi bagi yang tidak menjalankan maka semua warga sekolah dengan sendirinya akan terdorong untuk melaksanakannya. ${ }^{15}$

Model Penenerapan budaya religius melaui model struktural ialah penciptaan budaya religius yang disemangati oleh adanya peraturan-peraturan, pembangunan kesan, baik dari dunia luar atas kepemimpinan atau kebijakan suatu lembaga pendidikan atau suatu organisasi. Model ini biasanya bersifat "top-down", yakni kegiatan keagamaan yang dibuat atas prakarsa atau instruksi dari pejabat atau pimpinan atasan.

Model penciptaan budaya religius ini terlihat dalam penyusunan aturan dan tata tertib yang mewajibkan bagi seluruh warga sekolah untuk melakasanakannya. Selain itu juga terlihat dalam struktur program ektrakurikuler yang mamasukkan pembelajaran al Qur'an dan tadarus, serta tercantumnya pembelajaran madin dan shalat dhuha berjamaan dalam jadwal pelajaran.

\section{b. Model Formal}

Penerapan budaya religius yang menggunakan model formal atau semangat keyakinan atas kehidupan manusia setelah

${ }^{15}$ Hasil wawancara dengan kepala sekolah SD Al Mahrusiyah Lirboyo Kediri pada tanggal 25 April 2017. 
Penerapan Budaya Religius... Oleh: Wasito \& Moh. Turmudi

mati. Bahwa kehidupan manusia yang sejati adalah kehidupan setelah mati, dan hidup di dunia merupakan tahap yang harus dilalui oleh manusia untuk mencari bekal untuk kehidupan setelah mati. Sementara bekal tersebut berupa menjalankan perintah agama dan meninggalkan larangan agama. Untuk itu, membiasakan anak untuk melaksanakan kewajiban agama merupakan suatu langkah agar kelak ketika anak dewasa tetap menjaga dan menjalankan perintah agama.

Sebagai lembaga pendidikan yang berbasis pesantren, SD Al Mahrusiyah Lirboyo Kediri tentunya akan lebih memfokuskan aktualisasi nilai-nilai dan ajaran Islam dalam kehidupan sehari-hari. Sebagaiamana yang dijelaskan oleh kepala Sekolah SD Al Mahrusiyah yang menyatakan bahwa :

Kami berharap lulusan SD Al Mahrusiyah memiliki kelebihan dengan sekolah SD lainnya. Kelebihan tersebut adalah kedisiplinan seseorang dalam menjalankan ajaran agama (shalat) Islam, baik itu yang diwajibkan maupun yang disunnahkan. Untuk itu, kami memberikan waktu tersendiri untuk membiasakan anak menjalankan shalat sunnah (dhuha) dan shalat dhuhur berjamah. Selain itu untuk mengasah kemampuan siswa dalam melakukan ibadah, kami menggilir siswa menjadi Imam dalam shalat, sementara guru menyimak dan setelah shalat guru akan menjelaskan dan menunjukkan apa yang masih kurang benar dalam pelaksanaan shalat tadi. ${ }^{16}$

Pernyataan diatas menunjukkan keseriusan SD Al Mahrusiyah dalam mengembangkan budaya religius di sekolah. Karena penting untuk membiasakan anak melaksanakan ajaran agama sejak dini namun dalam suasana yang menyenangkan.

Islam adalah agama yang sangat sarat dengan ritual, dalam sehari terdapat lima waktu yang diwajibkan untuk malaksanakan ritual yang disebut dengan shalat lima waktu (maktubah), yaitu;

${ }^{16}$ Hasil wawancara dengan kepala sekolah SD Al Mahrusiyah Lirboyo Kediri pada tanggal 25 April 2017.

Volume 29 Nomor 1 Januari-Juni 2018 
Penerapan Budaya Religius... Oleh: Wasito \& Moh. Turmudi

subuh, dhuhur, 'asyar, maghrib, dan isya'. Selain shalat maktubah sebagai ritual yang diwajibkan kepada seluruh umat Islam, juga terdapat kewajiban lain sebagai rukun yang harus dilaksanakan/ditunaikan oleh seluruh umat Islam, diantaranya zakat, puasa dan haji, belum lagi ritual yang bersifat sunnah hukumnnya. Dikarenakan banyaknya ritual keagamaan yang harus ditunaikan oleh umat Islam, maka diperlukan kesungguhan dan keikhlasan dalam melaksanakannya. Untuk mencapai hal tersebut, membiasakan melaksanakan kewajiban dan ajaran agama Islam sejak usia dini sangat dibutuhkan. Karena jika tidak dibiasakan sejak usia dini, maka ketika individu telah dewasa akan sangat merasa keberatan.

Usaha yang dilakukan oleh SD Al Mahrusiyah agar ketika dewasa nanti siswa selalu menjalankan perintah dan ajaran Agama adalah dengan membiasakan anak melaksanakan shlat dhuha dan shalat dhuhur secara berjamaah.

Model Penenerapan budaya religius melaui model formal yaitu penciptaan budaya religius yang didasari pemahaman bahwa pendidikan agama adalah upaya manusia untuk mengajarkan masalah-masalah kehidupan akhirat saja atau kehidupan ruhani saja. Model ini biasanya menggunakan cara pendekatan keagamaan yang bersifat normatif, doktriner dan absolutis. Peserta didik diarahkan untuk menjadi pelaku agama yang loyal, komitmen, dan berdedikasi.

Model penerapan budaya religius seperti ini terlihat dalam pembelajaran al Quran yang dimasukkan ke dalam program ekstra kuikuler serta pembelajaran madarasah diniyah yang dilaksanakan setelah shalat dhuha berjamaah.

\section{c. Model Mekanik}

Etika dan akhlak merupakan ciri khas dari pendidikan pesantren, dimana selama ini pesantren merupakan satu-satunya lembaga pendidikan yang mampu membentuk etika dan akhlak para santrinya. Karena bagaimanapun juga manusia merupakan 
makhluk sosial yang tidak bisa hidup tanpa bantuan orang lain, sehingga dalam berinteraksi dengan orang lain diperlukan etika dan akhlak untuk menjaga perasaan orang lain. Bahkan dalam Islam akhlak merupakan hal yang sangat penting dalam kehidupan bermasyarakat, sebagiamana yang dikatan oleh Nabi Muhammad SAW, "sesungguhnya saya diutus untuk memperbaiki akhlak".

Dalam hal ini, SD Al Mahrusiyah menyusun peraturan yang mewajibkan kepada seluruh warga sekolah untuk mengutamakan kesopanan, baik sesama siswa, kepada guru, dan kepada semua orang yang berada di sekelilingnya. Peraturan tersebut diantaranya membiasakan mengucapkan salam ketika bertemu dengan orang lain yang dikenalnya, murah senyum dan menghormati hak orang lain. Dan jika ada siswa yang melanggar peraturan tersebut, maka akan diberikan sanksi berupa menulis surat pendek sebanyak-banyaknya (bersifat kondisional). Sebagaimana yang dinyatakan oleh kepala sekolah melalui wawancara :

Untuk menjaga dan membiasakan para siswa berperilaku sopan, kami menyusun aturan yang harus dijalankan oleh semua siswa, dan yang melanggar akan dikenai sanksi. Tetepai sanksi tersebut bersifat mendidik dan mengasah kemampuan siswa, seperti menuliskan lafadz basmalah sebanyak 100 kali atau menghafal asma'ul husna. ${ }^{17}$

Model Penenerapan budaya religius melaui model mekanik yaitu penciptaan budaya religius yang didasari oleh pemahaman bahwa kehidupan terdiri atas berbagai aspek; dan pendidikan dipandang sebagai penanaman dan pengembangan seperangkat nilai kehidupan, yang masing-masing bergerak dan berjalan menurut fungsinya. Masing-masing gerak bagaikan sebuah mesin yang terdiri atas beberapa komponen, di mana

${ }^{17}$ Hasil wawancara dengan kepala sekolah SD Al Mahrusiyah Lirboyo Kediri pada tanggal 25 April 2017.

Volume 29 Nomor 1 Januari-Juni 2018 
setiap komponen menjalankan fungsinya masing-masing, dan lbisa saling berkonsultasi atau tidak dapat berkonsultasi. Model tersebut berimplikasi terhadap pengembangan pendidikan agama yang lebih menonjolkan fungsi moral dan spiritual atau dimensi afektif daripada kognitif dan psikomotorik.

Model penerapan ini dapat dilihat dari tata tertib tentang kesopanan dan senyum, sapa, serta salam dalam berinteraksi dengan sesamanya. Penanaman moralitas dan norma-norma social yang sejalan dengan Islam perlu ditanamkan pada anak usia sekolah (Sekolah dasar). Karena usia ini anak sudah mulai menginternalisasikan nilai-nilai dan norma-norma sosial kedalam dirinya. Menurut Goerge Harbert Mead bahwa anak usia sekolah dasar berada dalam tahap play stage, yaitu proses dimana individu belajar mengetahui perannya dalam lingkungan sosial. Dan pengalaman individu mulai lahir hingga remaja (tahap game stage) akan diakumulasikan dan di generalisasi menjadi kepribadian diri (tahap generalized other) pada masa dewasa. Hal ini dikarenakan untuk mencapai individu yang sempurna, seseorang harus menjadi anggota komunitas dengan menunjukkan dengan kesamaan sikap dengan sikap komunitas dimana ia tinggal. ${ }^{18}$

d. Model organik,

Model Penenerapan budaya religius melaui model organik yaitu penciptaan budaya religius yang disemangati oleh adanya pandangan bahwa pendidikan agama adalah kesatuan atau sebagai sistem (yang terdiri atas komponen-komponen yang rumit) yang berusaha mengembangkan pandangan/semangat hidup agamis, yang dimanifestasikan dalam sikap hidup dan ketrampilan hidup yang religius. Model penciptaan budaya religius ini berimplikasi terhadap pengembangan pendidikan

${ }^{18}$ Zaenal Arifin, Perilaku Remaja Pengguna Gadget: Analisis Teori Sosiologi Pendidikan, Tribakti; Jurnal Pemikiran Keislaman, Vol. 26 No. 2, 2016, h. 297. 
Penerapan Budaya Religius... Oleh: Wasito \& Moh. Turmudi

agama yang dibangun dari fundamental doctrins dan fundamental values yang tertuang dan terkandung dalam alQur'an dan al-Sunnah sebagai sumber pokok. Kemudian bersedia dan mau menerima kontribusi pemikiran dari para ahli serta mempertimbangkan konteksnya.

Penerapan budaya religius model organik ini tergambar dalam proses internalisasi ajaran Islam dalam materi pelajaran Pendidikan Agama Islam, Madrasah Diniyah, dan ceramahceramah keagamaan yang diadakan pada penringatan-peringatan hari besar Islam.

\section{Penutup}

Berdasarkan paparan data dan pembahasan di atas, penelitian ini menyimpulkan bahwa:

1. Bentuk-bentuk budaya religius di SD Al Mahrusiyah meliputi belajar baca tulis al-Qur'an dan tadarrus, pemakaian busana muslim, pelaksanaan shalat jamaah di sekolah, kegiatan madin, pembiasaan senyum, sapa dan salam, berperilaku sopan santun kepada semua warga sekolah, dan doa bersama, serta peringatan harihari besar agama Islam.

2. Model penerapan budaya religius di SD Al Mahrusiyah meliputi 4 (empat) model, yaitu: pertama model struktural (melalui kebijakan dan peraturan), kedua, model formal (menanamkan commitment dan dedikasi untuk menjalankan ajaran agama), ketiga, model mekanik (membangun dan membiasakan berperilaku sopan dan santun terhadap sesama), dan keempat, model organik (melalui internalisasi dan ntransformasi pengetahuan tentang ajaran agama yang bersumber pada al Quran dan Hadits). 
Arifin, Zaenal. Perilaku Remaja Pengguna Gadget: Analisis Teori Sosiologi Pendidikan, Tribakti; Jurnal Pemikiran Keislaman, Vol. 26 No. 2, 2016

http://nuansakomunikasi.blogspot.co.id/2012/11/pakaian-danmakna-simbolik.html.

Koentjaraningrat. Kebudayaan, Mentalitas dan Pembangunan. Jakarta: Gramedia, 1989.

Muhaimin, dkk. Paradigma Pendidikan Islam: Upaya Mengefektifkan Pendidikan Agama Islam di Sekolah. Bandung: Remaja Rosdakarya, 2008.

Muhaimin. Rekonstruksi Pendidikan Islam: Dari Paradigma Pengembangan, Manajemen Kelembagaan, Kurikulum hingga Strategi Pembelajaran. Jakarta: Raja Grafindo Persada, 2009. 